\title{
Autophagy Protein 5
}

National Cancer Institute

\section{Source}

National Cancer Institute. Autophagy Protein 5. NCI Thesaurus. Code C104964.

Autophagy protein 5 ( $275 \mathrm{aa}, \sim 32 \mathrm{kDa}$ ) is encoded by the human AT G5 gene. This

protein plays a role in autophagy and may play a role in apoptosis. 